\title{
Does Pastoralists' Participation in the Management of National Parks in Northern Norway Contribute to Adaptive Governance?
}

\author{
Camilla Risvoll $^{1}$, Gunn Elin Fedreheim ${ }^{2}$, Audun Sandberg ${ }^{1}$ and Shauna BurnSilver ${ }^{3}$
}

\begin{abstract}
Norwegian protected areas have historically been managed by central, expertise bureaucracy; however, a governance change in 2010 decentralized and delegated the right to manage protected areas to locally elected politicians and elected Sámi representatives in newly established National Park Boards. We explore how this new governance change affects adaptive capacity within the reindeer industry, as the reindeer herders are now participating with other users in decision-making processes related to large tracts of protected areas in which they have pasture access. Aspects within adaptive capacity and resilience thinking are useful as complementary dimensions to a social-ecological system framework (Ostrom 2007) in exploring the dynamics of complex adaptive social-ecological systems. The National Park Board provides a novel example of adaptive governance that can foster resilient livelihoods for various groups of actors that depend on protected areas. Data for this paper were gathered primarily through observation in National Park Board meetings, focus groups, and qualitative interviews with reindeer herders and other key stakeholders. We have identified certain aspects of the national park governance that may serve as sources of resilience and adaptive capacity for the natural system and pastoral people that rely on using these areas. The regional National Park Board is as such a critical mechanism that provides an action arena for participation and conflict resolution. However, desired outcomes such as coproduction of knowledge, social learning, and increased adaptive capacity within reindeer husbandry have not been actualized at this time. The challenge with limited scope of action in the National Park Board and a mismatch between what is important for the herders and what is addressed in the National Park Board become important for the success of this management model.
\end{abstract}

Key Words: adaptive capacity; decentralization; national park governance; participation; pastoralists; protected areas; reindeer herding; SES framework; social-ecological systems

\section{INTRODUCTION}

Protected areas have for a long time been considered a critical tool for securing biodiversity (Sanderson et al. 1998, West et al. 2006, Zimmerer 2006), and the sole aim of these areas has been to preserve or conserve nature and safeguard basic ecosystem services. However, many protected areas globally also include human user groups, in which people continue to carry out livelihood activities (Bedunah and Schmidt 2004, Lockwood et al. 2006, Riseth 2007, Bay-Larsen and Fedreheim 2008, Sandberg 2008). In this situation, protected areas are thus an arena where various actor groups exist and interact-hikers, hunters, pastoralists, tourist operators, and managers. Our focal point of study is seven protected areas in central Nordland, Norway, where reindeer herders of the Sámi ethnic group continue to herd their animals. Fig. 1 shows the protected areas (shaded in red), and almost all of Nordland County is considered reindeer pasture, divided between four reindeer districts (siidas). Protected areas have played a particularly critical role in safeguarding pastureland for reindeer and sheep grazing, in contrast to nonprotected land where land use changes such as encroachments and fragmentation are inevitable challenges for the pastoral communities in Norway (Rybråten and Hovelsrud 2010).

Norwegian protected areas have historically been state managed by a central bureaucracy with expertise in conservation. This model was heavily criticized for excluding stakeholder interests, both in establishing protected areas and in the management of these areas (St.meld.nr.62 (1991-1992) 1992). A 2006 report by the Office of the Auditor General also criticized Norwegian environmental authorities for not safeguarding conservation values, and concluded that $30 \%$ of Norway's protected areas were threatened, an increase from 18\% in 1995 (Office of the Auditor General of Norway 2006). The criticisms included insufficient
Fig. 1. Protected areas in Central Nordland, Norway.

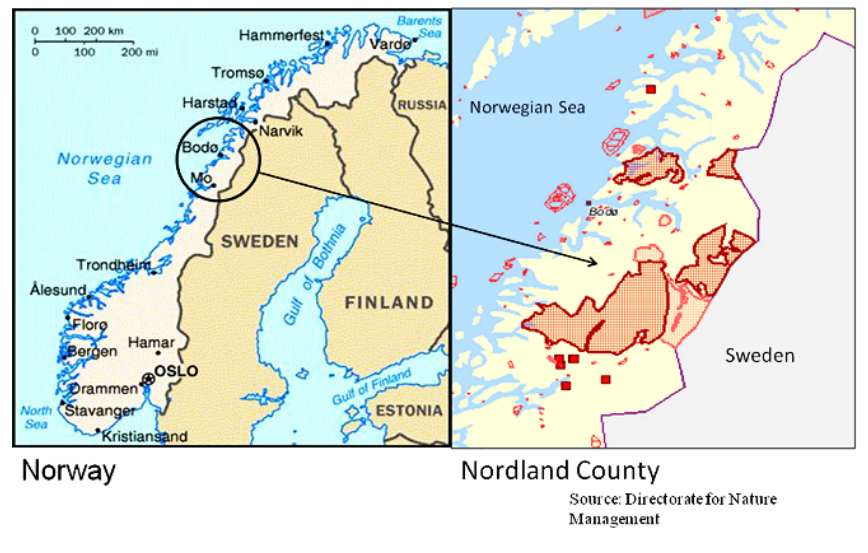

revision of management plans for protected areas, and poor implantation of measures in these plans. The report asked if Norway had been too preoccupied with establishing protected areas while overlooking the processes necessary for their management. Clearly, there was an acknowledged need for change in the management of protected areas, and a governance change occurred in 2010. The management of Norway's national parks (NPs) was decentralized, and the right to manage protected areas was delegated to locally elected politicians and elected Sámi representatives in newly established Regional National Park Boards (NPBs) (Solheim 2009, Ministry of Environment 2010). In addition, local stakeholders are now represented in Professional Advisory Committees (PACs), consequently 
enabling recreational and tourism interests, farmers, reindeer owners, and landowners the opportunity to actively participate in management of protected areas in their local communities. Working Committees (WCs) were established to take care of matters that have less influence on protected area values.

An explicit aim with this governance change is to ensure that local knowledge and interests are integrated as part of protected area management in order to increase protected areas' legitimacy and to contribute to more smoothly running NPs and more local development. This change means that stakeholders for the first time in almost 50 years (since the first NP was established) are invited to participate in decision-making related to the use of the large tracts of land for pasturing, hunting, fishing, hiking, and tourism that now are included in the protected areas. Thus, the fact that management decisions now are made by land users' own elected politicians suggests that local needs are increasingly taken into account (Fauchald and Gulbrandsen 2012).

We examine how this new change in governance affects the adaptive capacity of pasturing operations in view of the challenges posed by climate change, conservation regulations, fragmentation of pastures, and increasingly stronger modernization and mechanization drives. With more local governance instead of distant bureaucratic management, the social and the ecological parts of the system are brought closer, and the NP system in the region has assumed more of a socialecological system (SES) character. The users of the resource systems are to a large extent also the actors in the governing systems, which permits us to use some of the tools of SES analysis to explain the changes in governing practices and in adaptive capacity. However, this also means that the traditional ecological knowledge and the specialized knowledge of stakeholders are not "objective" scientific facts about nature's values but represent "interests," and thus need to be analyzed in a systematic way that incorporates both ecosystem and social system processes. We use the pastoral industries - sheep grazing, goat grazing, and reindeer grazing - as the prominent example. Because sheep and goats are grazed outdoors only in the summer, we focus more on the reindeer pastoral activities and analyze in particular the challenges within the reindeer industry. Given the new management responsibility, reindeer owners are now participating in decision-making processes with other users. An important aspect within such a governance setting is the multiple drivers of change that these SESs are facing. Among these drivers are political, institutional, and biophysical processes alongside the many interests that have a stake in the SES in focus.

\section{From central expert management to local and regional} governance in Norway-Why did it happen?

Several factors have influenced the devolution process of protected area governance. First, Norway fulfilled its second NP plan (St.meld.nr.62 (1991-1992) 1992); thus, a 100-year-long process of establishing protected areas was completed. With this fulfillment, Norway also met international (IUCN) demands regarding the proportion of land area in all countries $(15 \%)$ that should be under nature protection. Second, by increasing the role of local knowledge in governance of protected areas, it is also believed that the quality and the legitimacy of this governance will increase. Third, devolution of management rights is also a response to ongoing and lengthy constitutional processes of recognizing "indigenous and local rights to land and water."
Norway's approach to implementing the "new conservation paradigm" (IUCN 2003, Bushell and Eagles 2007) aims to increase local participation in conservation processes (Castro et al. 2006, Bay-Larsen 2010) and stimulate the sustainable use of protected areas. This involves both pasturing and the promotion of increased nature-based tourism in protected areas (St.prp. $\mathrm{nr}$ 65 (2002-2003) 2003, Fedreheim 2013) in order to contribute to more viable livelihood opportunities among local people.

The overall political objective of the reform was to create mechanisms and processes that would benefit the local societies that were affected by the decisions to protect large areas of nature. The NPBs' main responsibilities are to develop and revise management plans, evaluate the need for specific management measures, evaluate applications for exemptions from the regulations, inform and put up signs, and monitor the areas (Solheim 2009), while the daily responsibility is given to park rangers. This implies that governance rights have been transferred from national, central expertise to the local/regional political level, leaving this governance level with the main responsibility for "operating the SESs" that preserve nature values and provide nature experience and recreational services to regional, national, and growing international populations.

Fig. 2 illustrates the institutional structure of protected area governance in Norway before and after the new model that was implemented in 2010, and the arrows between different levels represent interactions that are critical to produce certain outcomes (Ostrom 2009). Prior to the new NP model, little opportunity for interaction and deliberation existed among different local users, and the former structure exhibited only downward linkages between the different levels, from national to regional and local levels (Fig. 2). Past protected area management was delegated to the County Governors (the Norwegian state's representatives), and all matters were governed at that level by expertise bureaucrats who implemented state conservation policy. The local users of the protected areas had no means of participating in any management or decision-making arenas. With the decentralization of power, a two-way interaction between levels was established (Fig. 2). The local and regional levels are connected to each other through the NPBs and PACs, and with the national level through the Provincial Environmental Administration and the National Environment Directorate. With such connections, the potential exists, in principle, for building relationships that can lead to outcomes of social learning and increased adaptive capacity.

An important question then is "To what extent can the creation of this new arena solve the fundamental dilemmas connected to the increased use of protected areas and conflicts between different actors/users, and at the same time provide legitimacy for conservation decisions?"

Modernization and increased competition among interest groups Establishing NPs has consequences for the wider SESs. In Scandinavia, the traditional pasturing of reindeer, sheep, and goats has been allowed to continue after the establishment of NPs, with only a few changes in the governing systems regulating their mode of exploiting the pastures. Such changes include restrictions on the use of motorized transportation for tendering the animals and transporting out dead/injured animals. Moreover, putting up fences might be allowed after applying to a NPB. 
Fig. 2. Cross-scale linkages before and after the new national park (NP) model. (NPB: National Park Board; PAC: Professional Advisory Committee; WC: Working Committee)

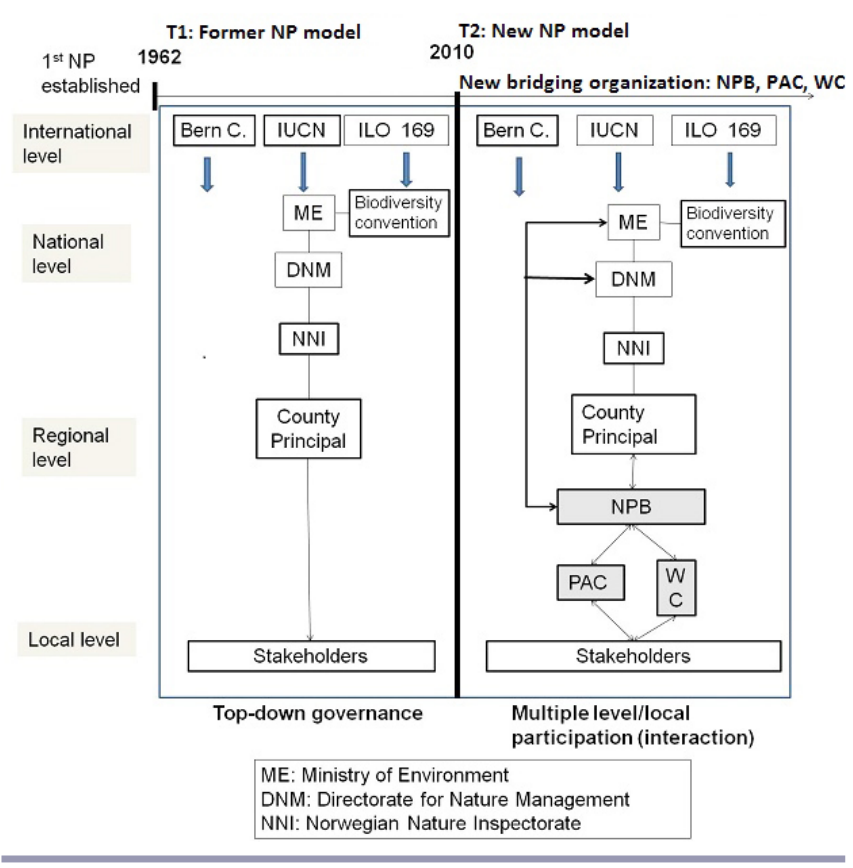

Certain trajectories of change have implications for the adaptive capacity of reindeer herders, and the ongoing modernization processes of animal husbandry, with its increased mechanization and altered strategies for operating grazing enterprises, have largely contributed to this. These changes have led to more extensive pasturing practices and less human presence with the flocks, which in some respects have increased the vulnerability of domestic reindeer in a wild environment. The international focus on protecting endangered species and preserving biodiversity, which has been implemented in the legislation of the northern countries (Sandberg 1999), has resulted in a dramatic increase in populations of large predators in northern Europe over the past 50 years. While large wild predators are part of the valued biodiversity of the ecosystem, they are considered a menace by local resource users who now depend on a modernized animal husbandry system.

Area protection is to some extent experienced as a challenge for reindeer husbandry (Holte 2008, Riseth and Holte 2008). Although protected areas initially provided the means to safeguard these pastures/ecosystems from encroachments such as increased infrastructure, motorized transportation, and resource extraction, conservation decisions may subsequently have led to increased human traffic in sensitive herding areas and more disturbance by tourism. Aspects of "the new protected area paradigm," where emphasis is on seeing local communities as economic and cultural beneficiaries of protected areas (Niedzialkowski et al. 2012), thus provide a challenge to reindeer husbandry. Alongside the traditional use of pasturing, hiking, logging, hunting, and fishing, more and new types of tourists have been introduced in the protected areas. These are horseback tourists, dog sledge tourists, mountain bike tourists, wheelchaired tourists, and kiting tourists. A more "universal design" for park paths to allow for various groups of handicapped persons also puts additional pressure on park ecosystems in terms of a need for more elaborate infrastructure. Accordingly, more and new arrangements such as signs and sounds will appear in order to accommodate all needs. Thus, both modernized pastoralism and new types of modern tourism have the potential to create completely new kinds of conflicts between different actors that depend on various ecosystem services from the same protected area.

Subsequent sections of this paper outline methods and the theoretical perspective and framework used to study the new NP governance change. We then present data on how reindeer herders perceive these pressures, and their perceptions for adaptation in light of these challenges. Subsequently, we examine interactions within the new protected area model in Nordland, what implications these interactions have for the adaptive capacity of the reindeer sector in the region, and how the NPB, PAC, and WC provide new connections between different levels, with potential for desirable outcomes.

\section{METHODS AND THEORETICAL FRAMEWORK}

In order to explore the research question related to these new ways of governing protected areas, we studied a reindeer pasture system and one NPB in the county of Nordland, Norway. This NPB manages seven protected areas, including four NPs. We studied the establishment of this board, observed stakeholder meetings, and conducted semistructured interviews and focus group interviews with actors in the pastoral communities to gauge presence or absence of outcomes in order to assess whether adaptive capacity of herders has increased. We observed five out of six NPB meetings in 2010/2011 as well as two meetings between the NPB and the PACs in 2011 and 2012. Interviews were conducted with seven reindeer owners from the area. One group interview with four reindeer owners was conducted, in addition to three individual interviews and one follow-up interview of herders. Additionally, in June 2011, we conducted a focus group interview with 16 local users and administrators (eight reindeer owners, two tourism operators, three public officials, two NP guides, and one person from the Norwegian Nature Inspectorate). Subsequent follow-up interviews with key actors, such as the chair of the NPB and two park rangers, were conducted in February 2013.

These interviews allowed us to investigate perspectives from many angles and triangulate the in-depth interviews. All interviews were transcribed twice by separate data analysts, checked for accuracy, and synthesized separately. Notes from our observations in the meetings were distributed among the researchers and analyzed to separate out the focal points relevant to our core research question. As supplementary data, we used public minutes from the meetings, and written submissions from NP management plans that had been released for public hearings. These documents are available online. The interviews were triangulated with other sources of information, such as newspaper articles and Internet sites.

We used a systems perspective and the SES framework (Ostrom 2007, 2009, Ostrom et al. 2007) as a tool to frame the complex challenges of protected area governance. The SES framework is potentially suitable for studying a wide array of ecological and 
social performances and effects of changes in institutional arrangements and human behavior in societies, as a way to understand interactions between humans and nature. The main assumption here is that the complexity is decomposable into components that are interrelated (Ostrom 2007), and the SES framework emphasizes four primary components: (1) resource system (RS), (2) resource unit (RU), (3) governance system (GS), and (4) actor (A).

We focused on the new governance system around NPs in Norway, where the actors participate in the governing of the resources they use. The resource system also includes the pastures that actors' reindeer graze within and share with wild herbivores and predators. We can define the NPs located in central Nordland as RSs occurring within larger SESs. In these RSs, there are both competing wild herbivores (including birds and rodents) and predators that do not discriminate between wild and domestic animals. The RU is the reindeer, while the human resource users (A) are the owners of the livestock (reindeer, sheep, and goats) who hold pasturing rights in this area, the licensed hunters who harvest from the wildlife, and the hikers and tourists who harvest experiences as a public good but who also affect both wild and owned animals with their presence and their trails. Together, these are the significant actors in relation to the GS of NPs and adjacent pasturing areas. Traditional use of the SES as well as the knowledge people have of the SES as a whole, and particularly knowledge about pastoralism in this SES, play an important role for the adaptive capacity of reindeer husbandry.

The NP model introduced in 2010 by the Norwegian government constitutes a new institutional arrangement that provides a means of collaboration among various stakeholders at different scales, and the creation of the NPBs, PACs, and WCs represents a potential "bridging organization" (Hahn et al. 2006). Such bridging organization often exists at the intersection of science and politics (Armitage et al. 2011), and nature conservation in Norway can be seen in such a light. Conservation at the national level is a policy field dominated by biologists (Falleth and Hovik 2009), while at the local level, politicians representing the relevant municipalities dominate the field (Bay-Larsen 2012, Fauchald and Gulbrandsen 2012). Until the creation of the NPBs with the PACs and WCs, local stakeholders did not have a decision-making or governance role to play at any scale. Within the new action arena, the opportunity exists for knowledge coproduction as an institutional mechanism that may enable learning (Armitage et al. 2011) and foster adaptive capacity.

Adaptive capacity is important in any multigovernance setting, such as the new NP model in Norway, in order to deal with change (Armitage and Plummer 2010). Tengö and von Heland (2011:40) define adaptive capacity in an institutional context as "the capacity of the institutional system to handle change and reconfigure itself without significant decline in crucial functions." With a delegation of more management responsibility to the local and regional levels, the wild ecological systems and the social systems influencing the governing systems are brought closer together, thus enhancing the potential for more flexible governance and a higher adaptive capacity.

However, the task of treating the dynamic causation that exists in the processes of ecosystem change and governance and institutional change presents some major challenges. Seeking to understand complex systems of people and nature requires comprehension of the nonlinearity and unpredictable dynamics in SESs. We assumed that the concept of linked social-ecological resilience is useful in this discourse, as it deals with the questions of how to live with recurrent change and with the ability to turn crises into opportunities in terms of exploiting such openings as a chance to move forward (Berkes et al. 2003).

Social learning is an important dimension of adaptive capacity and adaptation. Moreover, it reflects changes in understanding that can go beyond the individual and emerge within wider groups of actors (Reed et al. 2010, Armitage et al. 2011) through interactions such as those found in the bridging organization of the new NP model in Norway. Bridging organization is outlined by Armitage et al. (2011:996) as a mode of coproduction of knowledge, and they define it as "the collaborative process of bringing a plurality of knowledge sources and types together to address a defined problem and build an integrated or systemsoriented understanding of that problem." It is in this context that we see engagements between the Nordland NPB, PACs, and WCs.

In our attempt to use the SES framework in the analysis, we focused particularly on the second tier variables derived from the SES framework developed by Ostrom and colleagues in 2007 and 2009, which continues to evolve as more researchers and practitioners use it. These variables are derived from the primary components (RS, RU, GS, A), and they do not exist in isolation but interact and thereby produce outcomes (Cox 2011). Focusing on desired outcomes alone will allow only limited understanding of how the system works; however, applying the SES framework supplies us with certain tools to demonstrate the mechanisms behind central outcomes (Cox 2010). Thus, the SES framework can help us identify the most important components in relation to the capacity to adapt to changing ecologies and technologies and to see more clearly what interactions produce which outcomes. It is crucial to see the different variables in relation to the larger social-ecological structure of the NP system (Cox 2010). We did not attempt to categorically value the variables in the action situation. However, drawing upon resilience literature, we discuss how the structure of the SES function may impact adaptive governance among reindeer herders.

Table 1 lists the variables that we found were particularly relevant and were important attributes affecting the resilience and adaptive capacity of the system. Moreover, these variables are presented using the structure from the SES framework (Ostrom 2009): first tier variables are presented in uppercase letters; second tier variables are shown with a number (Table 1). The prime motivation was that applying the SES framework in this analysis was useful for building a common language for social-ecological analysis and thus enabling comparisons to be made across studies of different natural resource systems (Ostrom 2007).

\section{RESULTS}

Herders' perceptions of reindeer husbandry in national parks

Interviews with reindeer herders revealed several developments in the NPs as complicating factors for reindeer husbandry.

Conflicts among users (I4)

Reindeer herders noted that increased pressure from hikers in certain areas of the NPs is problematic for them because these 
Table 1. Second tier variables important for the analysis of national parks as social-ecological system (SESs). (NPB: National Park Board; PAC: Professional Advisory Committee; WC: Working Committee)

\begin{tabular}{|c|c|}
\hline SES Framework Variables & Features in the SES \\
\hline Resource System (RS) & National parks in central Nordland \\
\hline Sector (RS1) & Reindeer pastures \\
\hline Human-constructed facilities (RS4) & Snowmobiles, all-terrain vehicles, lorries, fences, cabins \\
\hline Resource Units (RU) & Reindeer \\
\hline Resource Unit mobility (RU1) & Movement between pastures \\
\hline Growth or replacement rate (RU2) & Calving \\
\hline Governance System (GS) & National parks and pasture areas \\
\hline Operational rules (GS5) & Dispensations \\
\hline Collective-choice rules (GS6) & National park management plans \\
\hline Constitutional rules (GS7) & Conservation regulations \\
\hline Monitoring and sanctioning processes (GS8) & Norwegian Nature Inspectorate and Fjelltjenesten \\
\hline Actors (A) & Within the national parks \\
\hline Number of actors (A1) & More/new actors with new management model \\
\hline History of use (A3) & Pastoralism \\
\hline Knowledge of SES/mental models (A7) & Cross-cultural dimension \\
\hline Interactions (I) & In the new bridging organization \\
\hline Information sharing (I2) & NPB/PAC/WC meetings \\
\hline Deliberation processes (I3) & NPB/PAC/WC meetings \\
\hline Conflicts (I4) & $\begin{array}{l}\text { New types of actors (foreign tourists, kiters) and } \\
\text { activities }\end{array}$ \\
\hline Outcomes $(\mathrm{O})$ & Social and environmental outcomes \\
\hline Social performance measures $(\mathrm{O} 1)$ & Coproduction of knowledge, efficiency, learning \\
\hline Ecological performance measures $(\mathrm{O} 2)$ & Ecosystem services, wildlife conservation, and others \\
\hline \multicolumn{2}{|c|}{ Related Ecosystems (ECO) } \\
\hline Flows into and out of focal SES (ECO3) & Predators \\
\hline
\end{tabular}

Source: Excerpts from McGinnis and Ostrom (2014), Table 1. As Elinor Ostrom and colleagues originally intended, the SES Framework is an open research framework. She encouraged everyone to contribute to its development and evolution.

areas are also key pastures for reindeers. Such recreational activities may increase the vulnerability of an ecosystem if they are not dealt with at an early stage. An example is the increased number of foreign tourists who are inexperienced in Norwegian mountains and lack knowledge about the traditional pastoral use of the areas (A3). These tourists are often not aware of the code of conduct, for instance regarding behavior near female reindeer during critical times (calving time) (Tyler et al. 2006).

Moreover, reindeer herders expressed concern about efforts put toward multiple organized activities and increased tourism because they mount up and place stress on reindeer husbandry. Interviews revealed that perceptions or world views (A7) about the SES differ distinctly between indigenous and nonindigenous representatives. Nonindigenous local representatives see increased activity and value creation in the protected areas as positive for the local community because it may allow the economy to prosper. Sámi representatives (all reindeer owners) perceive the increased activity as threatening to their industry. One reindeer herder in the focus group interview explained:

This land, we have used for reindeer herding for generations. Then someone comes to protect this land that we have protected for all these years. The Norwegian people think that their way of "protecting" is better than ours, but as a reindeer herder, the land becomes more fragile. It is not protection that is the problem; it is all the stakes people have in the protected area. It becomes crowded with people who don't know our livelihood. (authors' translation from focus group interview, June 2011)
Moreover, reindeer herders sense a dilemma by being in the NPB; for instance, sometimes they have the ability to prevent activities that will affect their livelihood negatively. Nevertheless, it becomes problematic for them to express skepticism about activities that receive support in society at large; for instance, arrangements enhancing health among people, such as hiking or bicycling. This shows how the pasturing resource system (RS) with its resource units (RUs) is interwoven with social systems that comprise other users of the same RS and RUs. Further, conflicts among users (I4) are evident in pasturing systems (Bay-Larsen and Fedreheim 2008), and it is the responsibility of the NPB to deal with such conflicts (Fedreheim 2013). How conflicts are dealt with obviously influences both the social $(\mathrm{O} 1)$ and the ecological $(\mathrm{O} 2)$ outcomes.

The need for information sharing among users (I2), and lack of knowledge about the interlinkages between resource system and resource units

Representation in the NPB is perceived as important by reindeer herders because they find it critical to participate in governance arenas where decisions that may affect their pasturing activities are made. One reindeer owner stated:

People don't know the reindeer sector. There are many more people in the mountains now than used to be when I grew up. People don't see the reindeer herd before they are in the middle of it, then it is too late and they frighten them away. We are not doing a satisfactory job informing people about our sector (authors' translation from focus group interview, June 2011) 
There was considerable support for this concern among the other herders in the focus group discussion. They identified the lack of knowledge about the reindeer industry, especially among foreign visitors to the NPs, as a major challenge, and thus see the need and feel a responsibility to provide better information about reindeer herding. They are, however, uncertain about how best to reach out with this information, and there is ambiguity about what to focus on in such information: the traditional ecofriendly reindeer herding or the more modern mechanized reindeer industry.

For the governance of protected areas, local ecological knowledge is a central aspect of the resilience of SESs because it plays an important role in sustaining the flow of ecosystem services (Berkes et al. 2009). It is thus important that the Sámi representatives' local and traditional ecological knowledge becomes visible in NPB meetings, for instance by geographically mapping crucial pasture resources, wildlife and fish resources, and areas of cultural importance. Because the Sámi representatives are also reindeer owners, this knowledge can be used to prevent roads, snowmobile trails, and hiking trails from being placed in conflict with calving areas or migration routes for reindeers.

Our data from observing the PAC meetings illustrate how important the cultural heritage and its connections to the mountain ecosystems are for the Sámi people. Reluctance in knowing what knowledge to share was also evident based on a fear that nonindigenous people may not be aware of the cultural significance of specific monuments. Thus, while information sharing (I2) is relevant, we suggest that the choice not to share certain information is also important to the study.

Deliberation processes (I3)

With the new governance system, interactions among multiple stakeholders (A1) are now possible (Fig. 2). However, stakeholder participation does not necessarily facilitate social learning (Reed et al. 2010), and there is a difference between the rights-holders category and the organized interests among the stakeholders. This analysis indicates that various constraints suppress this potential interaction among stakeholders from being actualized. First, focus group discussions and observations in NPB meetings revealed certain trade-offs related to a mismatch between what reindeer herders perceived as important for themselves in regard to protected area management and what actually takes place in the NPB meetings.

Particularly the park rangers, but also other members of the NPB, expressed frustration regarding the rigid and inefficient treatment of motorized transport dispensations. These matters occupy a large percentage of the NPB's agenda, leaving insufficient room for other agenda items. Fig. 3 illustrates that in most NPB meetings in 2012 and the beginning of 2013, dispensation matters comprised about $50 \%$ of the meeting time (Nordland National Park Board 2013b). An interview with park rangers revealed that in 2011, about $69 \%$ (i.e., 101 of 147 agenda items) comprised dispensation matters on motorized transport.

This time use leaves less room for knowledge sharing and communicating information in the meetings. Having time was perceived by reindeer herders as critical to achieve outcomes of coproduction of knowledge and learning. This situation suggests that deliberation in its various forms has varying effects on the
SESs, and the causal effects of deliberation will vary according to how deliberation is undertaken. The fact that the NPB has to deal with clear-cut cases such as dispensation applications means that there is less time to focus on information sharing (I2) and solving conflicts among users (I4), which in turn influences coproduction of knowledge (O1).

Fig. 3. Agenda items at National Park Board meetings.

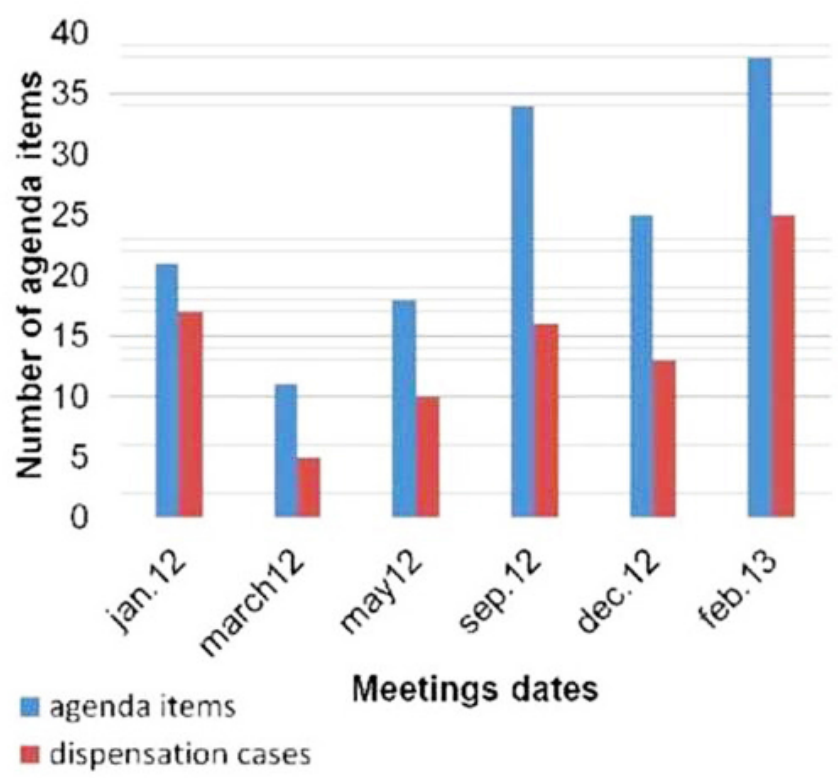

Second, although reindeer herders now participate in the NPB, they perceive the regulations from different levels (collectivechoice [GS6] and constitutional rules [GS7]) as constraining their scope of action and greatly affecting their efficiency (O1). Reindeer herders feel that they are not really participating in decision-making since they do not have the power to change the constitutional rules; instead, they feel that they function as spokespersons to comment on rules composed at a level far from their local reality. As members of the NPB, they must defend the NPB's operational decisions (GS5), even though as reindeer owners they see that these decisions might collide with the interests of their industry. Hence, they feel a loyalty dilemma, as once they are in the meeting, they represent the NPB, and once they walk out, they represent their livelihoods and business. One reindeer herder in the focus group interview expressed this dilemma:

\section{When I walk into the NPB meeting I must put on the "conservation hat" and represent conservation regulations, and once I walk out of the meeting I can be a reindeer herder again. (authors' translation from focus group interview, June 2011)}

Such perception is a reflection of a mismatch between the goals of devolution and deliberation (I3) on one side, and the reality perceived by the local actors. This provides a challenge for the new conservation governance model, and particularly for the legitimacy of the NPB. Another reindeer herder expressed her concern: 


\begin{abstract}
We must maneuver between so many government departments today, and one becomes so little. In theory there are many possibilities to do things, but our experiences from reality are very different. This makes me tired and powerless. (authors' translation from focus group interview, June 2011)
\end{abstract}

Similar frustration was addressed in a local newspaper, where the NPB expressed concern that the NPB as an institution is in theory enabling local management, but in reality is being completely controlled by the national conservation regulations (Andreassen 2013). Park rangers noted that although the state government has initiated regional and local participation, it has not changed regulations and external conditions framing the protected area management. This means in reality that many matters must be dealt with as they were prior to the introduction of the new governance model, and that the operational rules (GS5) remained the same after the introduction of the new model (Fedreheim 2013).

While the new conservation model has provided a mechanism for local participation, the limited scope of action becomes a challenge to the success of this management model. The potential for knowledge sharing (I2) and coproduction of knowledge is so far not being fulfilled, partly because the Norwegian state is constraining the interaction in the NPB by not allowing deliberation (I3) to prosper and social learning (O1) to develop. The rigidity in governance at upper levels is limiting the scope of action at the NPB level.

Interviews with park rangers and other representatives of the NPB revealed that regulations on use of motorized transport on bare ground by pastoralists are inflexible, unclear, and not adhered to, thus resulting in many conflicts with both the conservation regulations and conservationists', hunters', and hikers' associations. Such rigidity makes these cases difficult to deal with, and an additional constraining factor for the NPB's scope of action is the government's use of its right of appeal when it does not agree with decisions made by the NPB. In view of our SES analysis, this implies that state-level governance has been too occupied with the conflicts between various social systems and had limited time to go deeper into the interactions between the park ecological systems and the local social systems.

\section{Steps toward adaptation}

By observing in the NPB meetings, it became evident that discussions and decision-making have been conducted in a somewhat adaptive, trial-and-error manner. A park ranger pointed out that the NPB is still at the running-in stage, and that in addition to "training in Norwegian environmental policies and regulations," it takes time for the representatives to experience how best to handle the various cases that arise on their agenda. Following this, the ranger emphasized that the large focus and time spent on dispensation cases has kept the NPB from exploring social-ecological issues of high importance and formulating local policies for conservation and use.

However, since the beginning of the new model, the NPB has attempted to convince the state government that dispensation cases should be dealt with in a different arena from the NPB. At a meeting between the Ministry of Environment and the NPB in March 2012, they received positive signals on this matter
(Nordland National Park Board 2012a). In February 2013, mutual agreement was sought on delegation of certain management work to a smaller WC consisting of a park ranger, the NPB chair, one representative from the municipalities, and one representative from the Sámi parliament.

Subsequent follow-up interviews of park rangers have simultaneously revealed a recent focus in the NPB on progressing toward the reindeer herders' wish for information sharing. Attempts to systematize information about the reindeer sector to communicate it to other actors in protected areas and the wider society (also foreign hikers) are seen as an important conflict minimizing strategy (I4). This indicates that over time, the new governing system can achieve some of the attributes necessary to run a complex SES like four adjacent NPs.

\section{DISCUSSION}

Through the centuries, the social system of northern Europe has generated the introduction of domesticated herbivores into a complex wilderness. While sheep and goats use this wilderness for summer pasturing, reindeer use it year-round. Turning such areas into NPs adds other dimensions of complexity to the SES, particularly due to the political objectives of protecting the natural biodiversity and securing sustained ecosystem services in the face of the increasing number of actor groups that emerge. As we have shown, a simple ecosystem analysis does not suffice here because the increased local governance of conservation regimes that takes into consideration changing pasturing strategies and changing recreational preferences in a socialecological context represents more challenging dilemmas. Sheep and reindeer owners might in general support the principle of biodiversity but are skeptical about the predator part of this diversity in their own pastures. Reindeer owners also support the governance measures to secure sustainable ecosystem services from the NPs but not conservation measures that represent obstacles to their own increasingly mechanized operations. Other examples of complex human-nature relationships are regrowth/ reforestation, hunting competition from predators, and unsettled legal battles over indigenous and local property rights, which make most types of planning and governance more challenging than under centralized bureaucratic management (Berkes et al. 2009). SES analyses of the kind presented here can therefore explain the processes where local compromises are made and the way the nesting of governing institutions functions in these cases (Ostrom 2007).

With convincing analysis that specifies the interactions that produce certain outcomes, the superior governing level can more confidently issue assurances that it will accept the governing measures taken by the subordinate governing level. Thus, the national governance level should, with some credibility, be able to ensure the international governing organizations that the objectives of various treaty obligations, pertaining for instance to biodiversity and protected areas, are fulfilled with more local participation and greater flexibility in management. The devolution of governance responsibility and authority to a regional or local NPB offers a promising approach for planning and enhancing the local capacity to deal with change and uncertainty, and thus can be seen as an attempt to increase the adaptive capacity of the governing system (Kofinas and Chapin 2009). For example, the Finnmark Act of 2005, which turned over 
to the Sámi people about $95 \%$ of the area of Finnmark County (the northernmost county of Norway), called the Finnmark Estate, promotes the principle of flexible and locally determined harvesting levels of game as an integrated part of the strategy for increased adaptive capacity (Sandberg 2008).

\section{Interactions in national park governance}

Since its establishment in 2010, the new NP governance model in Norway has created an arena (NPB/PAC/WC) with opportunities for interaction across different levels of society. This new model provides an arena where politicians, park rangers, and Sámi representatives together have the opportunity to coalesce around shared concerns about protected areas and learn from each other to minimize conflicts. Linking this to the SES framework (Ostrom 2007) and the second tier variables (Table 1), opportunities for interactions (I2, I3, and I4 following the SES framework) are present with the new structure. In this complex process of governance change, the case from central Nordland shows that a bridging organization, such as establishing the NPB/PAC/WC, can be critical in terms of facilitating interactions among users (Shen and Tan 2012). Prior to the new NP model, no such opportunities for interaction regarding NP management existed at the local level; thus, this change in governance provides an important step toward the desired outcomes (Table 1). The NPB may ensure that the protection of large areas maintains its legitimacy with the local population and that practical solutions for conflicting usage (e.g., mechanized pasturing operations vs. nature-based tourism development) are sought at the lowest possible level.

\section{Trade-offs constraining the opportunity for knowledge coproduction and learning}

The new linkages and interactions in the NP governance reform provide opportunities for coproduction of knowledge and social learning, with a potential outcome of increased adaptive capacity within reindeer husbandry. However, these interactions have not yet translated into such desired outcomes $(\mathrm{O} 1, \mathrm{O} 2)$. While the new conservation model has provided a mechanism for local participation, solutions to the challenges of the limited scope of action in the NPB and the mismatch between what is important for the pastoralists and what is addressed in NPB meetings become important for the success of this management model. Thus, the legacy of the old structure prior to 2010 can prevent the adaptation in the new structure, as the path dependency to a large extent presents the board members with the role of local implementers of state policies as the most comfortable option. The delay in institutional change and the constrained scope of action increase the herders' feeling of powerlessness and can act as barriers to effective social learning and thus limit the adaptive capacity of the reform, especially for reindeer husbandry.

But as follow-up interviews revealed, there have been some promising opportunities recently where the NPB succeeded through an iterative process to make some structural changes to the action situations that they were facing. By relaxing the structure and increasing the time for dialogue during the NPB meetings, greater opportunity exists to increase the efficiency of NPB's executive work, opening up the potential for achieving desired outcomes in the SES. Such attempts to systematize, organize, and share herders' ecological knowledge and practices with society (Berkes 2009) can provide one important step in this direction.
Information sharing among different actors (I2) in the NPB is important for conflict resolution, and depends on the actors' knowledge of ecosystem dynamics and the forces of change in the various social systems and to what extent this knowledge is shared among users (Ostrom 2009). Such acknowledgement of pastoralists' changing needs, following increased interaction between managers of protected areas and local people, provides a promising learning ground for a more sustainable governance of total conservation resources (Chapin 2009). This is particularly important in the cross-cultural context of NP management in Norway because reindeer herders rely heavily on these protected areas for unfragmented pastures.

It is important to recognize and respect the self-governing capacity and resilience that is embedded in local and indigenous institutions. Such recognition and understanding of local protocol are central to ensuring local cooperation in times of change (Veland et al. 2010). Different knowledge systems are now employed in the NPB/PAC/WC governing activities, and this represents a challenge, but it may also provide a promising arena for increased mutual understanding and learning among different actors. Conversely, if ecological knowledge, both traditional and scientific, is not acknowledged when pastoral systems are being modernized, the uncritical introduction of modern industrialized models, including new slaughter strategies and flock structuring, might reduce the adaptive capacity of local pasturing systems. Further monitoring of this new direction of knowledge sharing toward opportunities for coproduction of knowledge and social learning will be an important field to study to ensure that this potential for increased adaptive capacity is realized. In an SES with reasonably clear boundaries, like the seven NPs in this study, the processes of knowledge exchange and learning can be observed in the coming years with the use of the SES framework. In this respect, the devolution of governing authority for NPs in Norway is also an interesting experiment for the further refinement and sophistication of the SES framework as an analytical tool.

Responses to this article can be read online at: http://www.ecologyandsociety.org/issues/responses. $\mathrm{php} / 6658$

\section{Acknowledgments:}

An early version of this paper was presented at the Second International Science and Policy Conference, Tempe, Arizona, USA, March 11-16, 2011 on "Resilience, Innovation, and Sustainability: Navigating the Complexities of Global Change": Theme: Governance, Polycentricity, Markets and Multilevel Challenges Panel: "Developing Frameworks to Study SocialEcological Systems Over Time" Many thanks to the actors in the Midtre Nordland National Park Board, and the reindeer herders whom we interviewed for their time and collaboration. Special thanks to Irene Pérez Ibarra for valuable insights and suggestions. We would like to thank the editors and the two anonymous reviewers for helpful comments on previous versions of this article. 


\section{LITERATURE CITED}

Andreassen, T. J. 2013. Plutselig sto hytta i en nasjonalpark, dermed ble Geir nektet å bygge vedbod [Suddenly the cabin stood in a national park, hence Geir was prevented to build a woodshed]. Avisa Nordland, January 2. [Online] URL: http://www.an.no/ nyheter/article6477269.ece

Armitage, D., F. Berkes, A. Dale, E. Kocho-Schellenberg, and E. Patton. 2011. Co-management and the co-production of knowledge: learning to adapt in Canada's Arctic. Global Environmental Change 21(3):995-1004. http://dx.doi.org/10.1016/ j.gloenvcha.2011.04.006

Armitage, D., and R. Plummer, editors. 2010. Adaptive capacity and environmental governance. Springer-Verlag, Berlin, Germany. http://dx.doi.org/10.1007/978-3-642-12194-4

Bay-Larsen, I. 2010. The conservationists' concerns: on national administration response to integrated use and protection planning. Local Environment 15(4):357-371. http://dx.doi.org/ http://dx.doi.org/10.1080/13549831003677688

Bay-Larsen, I. 2012. Bureaucrats and boundaries. The changing intersection between experts, local communities and environmental administration in nature protection. Dissertation. Department for Biosciences, Fisheries and Economics, University of Troms $\varnothing$, Norway.

Bay-Larsen, I., and G. E. Fedreheim. 2008. Kartlegging av konflikter i vernede områder i Nordland [Mapping of conflicts in protected areas in Nordland]. Working Paper No. 1005/2008. Nordlandsforskning, Bodø, Nordland.

Bedunah, D. J., and S. M. Schmidt. 2004. Pastoralism and protected area management in Mongolia's Gobi Gurvansaikhan National Park. Development and Change 35(1):167-191. http:// dx.doi.org/http://dx.doi.org/10.1111/j.1467-7660.2004.00347.x

Berkes, F. 2009. Indigenous ways of knowing and the study of environmental change. Journal of the Royal Society of New Zealand 39:151-156. http://dx.doi.org/10.1080/03014220909510568

Berkes, F., J. Colding, and C. Folke, editors. 2003. Navigating social-ecological systems: building resilience for complexity and change. Cambridge University Press, Cambridge, UK. http://dx. doi.org/10.1017/CBO9780511541957

Berkes, F., G. P. Kofinas, and F. S. Chapin, III. 2009. Conservation, community, and livelihoods: sustaining, renewing, and adapting cultural connections to the land. Pages 129-148 in F. S. Chapin, III, G. P. Kofinas, and C. Folke, editors. Principles of ecosystem stewardship: resilience-based natural resource management in a changing world. Springer-Verlag, New York, USA. http://dx.doi.org/10.1007/978-0-387-73033-2 6

Bushell, R., and P. F. J. Eagles, editors. 2007. Tourism and protected areas: benefits beyond boundaries. CAB International, Cambridge, UK. http://dx.doi.org/10.1079/9780851990224.0001

Castro, F. de, A. D. Siqueira, E. S. Brondizio, and L. C. Ferreira. 2006. Use and misuse of the concepts of tradition and property rights in the conservation of natural resources in the Atlantic Forest (Brazil). Ambiente e Sociedade IX(1):23-39. http://dx.doi. org/10.1590/S1414-753X2006000100002
Chapin, F. S., III. 2009. Managing ecosystems sustainably: the key role of resilience. Pages 29-53 in F. S. Chapin, III, G. P. Kofinas, and C. Folke, editors. Principles of ecosystem stewardship: resilience-based natural resource management in a changing world. Springer-Verlag, New York, USA. http://dx.doi. org/10.1007/978-0-387-73033-2__

Cox, M. 2010. Exploring the dynamics of social-ecological systems: the case of the Taos Valley acequias. Dissertation. School of Public and Environmental Affairs, Indiana University, Bloomington, Indiana, USA.

Cox, M. 2011. Applying a social-ecological system framework to the study of the Taos Valley irrigation system. Working Paper 1121. The Vincent and Elinor Ostrom Workshop in Political Theory and Policy Analysis, Indiana University, Bloomington, Indiana, USA.

Falleth, E. I., and S. Hovik. 2009. Local government and nature conservation in Norway: decentralisation as a strategy in environmental policy. Local Environment 14(3):221-231. http:// dx.doi.org/10.1080/13549830802692849

Fauchald, O. K., and L. H. Gulbrandsen. 2012. The Norwegian reform of protected area management: a grand experiment with delegation of authority? Local Environment 17(2):203-222. http:// dx.doi.org/http://dx.doi.org/10.1080/13549839.2012.660910

Fedreheim, G. E. 2013. Value creation on Norway's green gold: an analysis of policy formulation and implementation in the field of nature conservation. Dissertation. Sociology, University of Nordland, Bodø, Norway.

Hahn, T., P. Olsson, C. Folke, and K. Johansson. 2006. Trustbuilding, knowledge generation and organizational innovations: the role of a bridging organization for adaptive comanagement of a wetland landscape around Kristianstad, Sweden. Human Ecology 34:573-592. http://dx.doi.org/10.1007/s10745-006-9035$\underline{\mathrm{Z}}$

Holte, A. 2008. Reindriftas erfaringer og forslag til tillempinger i vernet av større sammenhengende naturområder [Reindeer experiences and suggestions for adaptations in the protection of large contiguous natural areas]. Report from the project Reindrift og nasjonalparker [Reindeer and national parks]. Published by author, Lillehammer, Norway. [Online] URL: http://www. reindrift.no/asset/1132/1/1132 1.pdf

International Union for Conservation of Nature (IUCN). 2003. The Durban accord: our global commitment for people and earth's protected areas. $\mathrm{V}^{\text {th }}$ IUCN World Park Congress. [online] URL: http://cmsdata.iucn.org/downloads/durbanaccorden.pdf

Kofinas, G., and F. S. Chapin, III. 2009. Sustaining livelihoods and human well-being during social-ecological change. Pages 5575 in F. S. Chapin, III, G. P. Kofinas, and C. Folke, editors. Principles of ecosystem stewardship: resilience-based natural resource management in a changing world. Springer-Verlag, New York, USA. http://dx.doi.org/10.1007/978-0-387-73033-2 3

Lockwood, M., G. L. Worboys, and A. Kothari. 2006. Managing protected areas: a global guide. Earthscan, London, UK. 
McGinnis, M., and E. Ostrom. 2014. Social-ecological system framework: Initial changes and continuing challenges. In P. Bots, M. Schlüter, and J. Senzimir, editors. A framework for analyzing, comparing, and diagnosing social-ecological systems. Special Feature Ecology \& Society 19(2):30. http://dx.doi.org/10.5751/ ES-06387-190230

Ministry of Environment. 2010. Opprettelse av interkommunalt nasjonalparkstyre for verneområdene knyttet til verneplanene for Saltfjellet-Svartisen, Junkerdal, Rago og Sjunkhatten i Nordland [Creation of inter-municipal National Park Board of protected areas related to protection plans for Saltfjellet-Svartisen, Junkerdal, Rago and Sjunkhatten in Nordland]. Letter from the Ministry of Environment, June 11. Oslo, Norway. [online] URL: http://www.bodofriluftsforum.no/sites/b/bodofriluftsforum.no/ files/112846052.pdf

Niedzialkowski, K., J. Paavola, and B. Jedrzejwska. 2012. Participation and protected areas governance: the impact of changing influence of local authorities on the conservation of the Bialowieza Primeval Forest, Poland. Ecology and Society 17(1):2. http://dx.doi.org/10.5751/ES-04461-170102

Nordland National Park Board. 2012a. Midtre Nordland nasjonalparkstyre i møte med miljøvernministeren. [Online] URL: http://nasjonalparkstyre.no/Midtre-Nordland/Nyhende/ Midtre-Nordland-nasjonalparkstyre-i-mote-med-miljovernministeren-/

Nordland National Park Board. 2013b. Sakspapir/saksframlegg. [Online] URL: http://www.nasjonalparkstyre.no/MidtreNordland/Styret/Styredokument/Sakspapir--saksframlegg/

Office of the Auditor General of Norway. 2006. Riksrevisjonens undersøkelse av myndighetenes arbeid med kartlegging og overvåking av biologisk mangfold og forvaltning av verneområder [The investigation of the government's efforts to survey and monitor biodiversity and management of protected areas]. Oslo, Norway. [online] URL: http://evalueringsportalen.no/evaluering/ riksrevisjonens-undersokelse-av-myndighetenes-arbeid-med-kartleggingog-overvaking-av-biologisk-mangfold-og-forvaltning-av-verneomrader

Ostrom, E. 2007. A diagnostic approach for going beyond panaceas. Proceedings of the National Academy of Sciences of the United States of America 104(39):15181-15187. http://dx.doi. org/10.1073/pnas.0702288104

Ostrom, E. 2009. A general framework for analyzing sustainability of social-ecological systems. Science 325 (5939):419-422. http://dx.doi.org/10.1126/science.1172133

Ostrom, E., M. A. Janssen, and J. M. Anderies. 2007. Going beyond panaceas. Proceedings of the National Academy of Sciences of the United States of America 104(39):15176-15178. http://dx.doi.org/10.1073/pnas.0701886104

Reed, M. S., A. C. Evely, G. Cundill, I. Fazey, J. Glass, A. Laing, J. Newig, B. Parrish, C. Prell, C. Raymond, and L. C. Stringer. 2010. What is social learning? Ecology and Society 15(4):1. [online] URL: http://www.ecologyandsociety.org/vol15/iss4/resp1/

Riseth, J. Å. 2007. An indigenous perspective on national parks and Sámi reindeer management in Norway. Geographical Research 45(2):177-185. http://dx.doi.org/10.1111/j.1745-5871.2007.00449. $\underline{\mathrm{x}}$
Riseth, J. Å., and A. Holte. 2008. Rennäring och nationalparker i Norge [Reindeer herding and national parks in Norway]. Pages 269-292 in C. Sandström, S. Hovik, and E. I. Falleth, editors. Omstridd natur: trender \& utmaningar $i$ nordisk naturförvaltning [Controversial nature: trends \& challenges in Nordic nature management]. Umeå Boréa Bokförlag, Umeå, Sweden.

Rybråten, S., and G. K. Hovelsrud. 2010. Local effects of global climate change: differential experiences of sheep farmers and reindeer herders in Unjárga/Nesseby, a coastal Sámi community in northern Norway. Pages 313-333 in G. K. Hovelsrud and B. Smit, editors. Community adaptation and vulnerability in Arctic regions. Springer, New York, USA. http://dx.doi.org/http://dx. doi.org/10.1007/978-90-481-9174-1 13

Sandberg, A. 1999. Conditions for community-based governance of biodiversity. Nordlandsforskning Report No. 11/99. Nordland Research Institute, Bodø, Norway.

Sandberg, A. 2008. Collective rights in a modernizing north-on institutionalizing Sámi and local rights to land and water in northern Norway. International Journal of the Commons 2(2):269287. [online] URL: http://www.thecommonsjournal.org/index. php/ijc/article/view/41/44

Sanderson, S. E., K. Brandon, and K. H. Redford. 1998. Parks in peril: people, politics, and protected areas. Island Press, Washington, D.C., USA.

Shen, X., and J. Tan. 2012. Ecological conservation, cultural preservation, and a bridge between: the journey of Shanshui Conservation Center in the Sanjiangyuan region, QinghaiTibetan Plateau, China. Ecology and Society 17(4):38. http://dx. doi.org/10.5751/ES-05345-170438

Solheim, E. 2009. Etablering av ny modell for forvaltning av verneområder - invitasjon til å delta i nasjonalpark-/ verneområdestyrer [Establishment of a new model for the management of protected areas: invitation to participate in National Park Conservation Boards]. Letter from the Ministry of Environment, December 14, Oslo, Norway. [online] URL: http://www.regjeringen.no/nb/dep/kld/dok/andre/brev/utvalgte brev/2009/ etablering-av-ny-modell-for-forvaltning-.html?id =588506

St.meld. nr. 62 (1991-1992). 1992. Ny landsplan for nasjonalparker og andre større verneområder i Norge [New land plan for national parks and other large protected areas in Norway]. Ministry of Environment, Oslo, Norway.

St.prp. nr. 65 (2002-2003). 2003. Tilleggsbevilgninger og omprioriteringer i statsbudsjettet medregnet folketrygden 2003 [Additional resources and priorities in the state budget including the National Insurance Scheme 2003]. Finance Department, Oslo, Norway.

Tengö, M., and J. von Heland. 2011. Adaptive capacity of local indigenous institutions: the case of the taboo forests of southern Madagascar. Pages 37-74 in E. Boyd and C. Folke, editors. Adapting institutions: governance, complexity and socialecological resilience. Cambridge University Press, Cambridge, UK. http://dx.doi.org/10.1017/CBO9781139017237.006

Tyler, N. J. C., J. M. Turi, M. A. Sundset, K. Strøm Bull, M. N. Sara, E. Reinert, N. Oskal, C. Nellemann, J. J. McCarthy, S. D. Mathiesen, M. L. Martello, O. H. Magga, G. K. Hovelsrud, I. 
Hanssen-Bauer, N. I. Eira, I. M. G. Eira, and R.W. Corell. 2006. Saami reindeer pastoralism under climate change: applying a generalized framework for vulnerability studies to a sub-Arctic social-ecological system. Global Environmental Change 17 (2):191-206. http://dx.doi.org/10.1016/j.gloenvcha.2006.06.001

Veland, S., R. Howitt, and D. Dominey-Howes. 2010. Invisible institutions in emergencies: evacuating the remote indigenous community of Warruwi, Northern Territory, Australia, from Cyclone Monica. Environmental Hazards 9:197-214. http://dx. doi.org/10.3763/ehaz.2010.0042

West, P., J. Igoe, and D. Brockington. 2006. Parks and peoples: the social impact of protected areas. Annual Review of Anthropology 35:251-277. http://dx.doi.org/10.1146/annurev. anthro.35.081705.123308

Zimmerer, K. S. 2006. Globalization \& new geographies of conservation. University of Chicago Press, Chicago, Illinois, USA. 